\title{
Use of Bee-attractants in Increasing Crop Productivity in Niger (Guizotia abyssinica. L)
}

\author{
Venkataramegowda Sivaram $^{1 *}$, Koragandahalli Venkateshappa Jayaramappa ${ }^{1}$, Anita \\ Menon $^{1}$ and Ruben Michael Ceballos ${ }^{2}$ \\ ${ }^{1}$ Department of Botany; Bangalore University; Bangalore-560 056 - India. ${ }^{2}$ Native American Research Laboraotry, \\ Division of Science and Mathematics; University of Minnesota-Morris; Morris, MN, 56267 - USA
}

\begin{abstract}
The use of bee attractants, Bee- $Q$ and Fruit Boost ${ }^{\mathrm{TM}}$ in the pollination of niger was evaluated. Bee visitations to niger flowers were observed for two weeks and an estimation of seed yield was determined. Different concentrations of Bee- $Q$ and Fruit boost ${ }^{\mathrm{TM}}$ were evaluated to understand honeybee visitation patterns on the target crop and pollination efficiency. Results indicate that applications of Bee-Q at $12.5 \mathrm{~g} /$ and Fruit boost at $0.75 \mathrm{ml} / \mathrm{lon}$ niger plots significantly increased the number of bee foragers over control plots. In addition, plots sprayed with these bee attractants significantly enhanced the seed set, seed weight, and germination of niger. This study suggests that pheromone-based bee attractants applied to niger can increase the marginal percentage of bee visitation, seed yield, and percent germination.
\end{abstract}

Key words: Bee-attractants, Honeybee, Guizotia abyssinica, Niger, Pollinators

\section{INTRODUCTION}

Niger is an important oilseed crop and its flowering phenology is highly responsive to crosspollination. Honeybees play an important role as a pollinator of the flowers of niger, which in turn cross-pollinates. Bambure (1958) found that flower heads of the species visited by honeybees had a higher average number of seeds when compared to flower heads without bee visitation. Panchabhavi and Rao (1978) reported that Apis florea serves as an important pollinator for this plant and sunflower under mixed crop conditions and recorded maxima of insect activity during morning hours of 09:00-09:30 a.m. Ramachandran and Menon (1979) found that the maximum amount of seed setting occurred in open pollinated plots. It also has been reported that bee pollination results in a $22-33 \%$ increase in niger yield (Panda et al. 1988) and that honeybees were the major pollinators $(91.30 \%)$. It is known that the absence of pollination by insects adversely affects seed yields (Rao and Suryanarayana 1990).

There has been a significant decrease in the number of domesticated honeybee colonies in India primarily due to increases in the number of viral diseases and pests. In addition to combating disease and parasites, there is a parallel interest in improving the pollinating efficiency of bees and overcoming pollinator deficits especially in areas where neighboring crops must compete for a limited number of pollinators (Levin and Anderson 1970). Under conditions of compromised pollinator efficacy, honeybee attractants may help to focus a limited number of pollinators onto a crop of interest (Delaplane and Mayer 2000). Of a handful of tested bee attractants (Mayer et al. 1989a,b; Elm storm and Maynard

*Author for correspondence: sivaram900@ gmail.com 
1991; Winston and Slessor 1993; Ambrose et al. 1995; Higo et al. 1995), those based on queen mandibular pheromone (QMP) - including, Fruit boost and Bee-Q - have shown the best results (Currie et al. 1992 a, b; Naumann et al. 1994). Increases in pollination and yield with application of bee attractants has been demonstrated in cucumber (Viraktamath and Anagoudar 2002; Pateel and Sattigi 2007), onion (Kalamath and Sattigi 2002) and radish (Chandrashekar and Sattigi 2009). The aim of this study was to examine bee attraction to a target crop (i.e., niger) upon application of bee attractants and to evaluate the usefulness of bee attractants in increasing pollination efficiency and yields for niger compared to untreated controls.

\section{MATERIALS AND METHODS}

\section{Experimental layout}

The experiment was conducted in an agricultural farm located $20 \mathrm{~km}$ from Bangalore, India during 2007- 2009. A niger crop was raised on one hectare of land using standard agricultural practices recommended by the Agriculture Department. Seven experimental plots, each with an area of $5 \mathrm{~m}^{2}$ and $2 \mathrm{~m}$ row spacing were set up on the farm. Commercially available bee attractants namely, Bee-Q (M.S. Excel Industries, Bombay, India) and Fruit Boost ${ }^{\mathrm{TM}}$ (Pherotech Inc.; Delta, BC, Canada) - were purchased for experimental applications. Attraction experiments were performed and treatment response curves were generated. In total, three concentrations of Bee-Q $(10,12.5$ and $15 \mathrm{~g} / \mathrm{l})$ and three for Fruit Boost $(0.5$, 0.75 and $1.00 \mathrm{ml} / \mathrm{l}$ ) were tested. Plots without spray served as controls.

\section{Treatment assignments}

From each plot, 10 flower heads were randomly selected (three plots per treatment) and were separately labeled with identifying tags. Two colonies of Apis cerana were introduced to the crop area, each having eight frame populations of honeybees. (It was also noted that there were a few natural colonies of Apis dorsata and Apis florea in the vicinity of experimental site). Bee attractants were sprayed on the bloom of Niger with a standard sprayer. Bee-Q was applied in the concentrations of $10,12.5$ and $15 \mathrm{~g} / \mathrm{l}$ on separate (and labeled) plots. Similarly, Fruit Boost was applied at concentrations of $0.5,0.75$ and 1.00 $\mathrm{ml} / \mathrm{l}$. (Different concentrations for each attractant were used to standardize for the differences in concentrations of active ingredients in the stock solutions purchased). Attractants were sprayed on flowers of Niger during different intervals (see Table 1). No bee attractant was applied to control plots. The number of honeybees visiting niger flowers sprayed with bee attractants was counted through visual observation. One observer was assigned to each plot and observations were synchronized to run between 08:00 a.m. to 04:00 p.m. at 2-hour intervals per day (Rao and Suryanarayana (1990). Each observer walked down each row for five minutes, recording the number of honeybee flower visits $(5 \mathrm{~min} . \mathrm{x} 3$ replicates $=15$ min per plot; 7 rows $\mathrm{x} 3$ replicates $=21 \mathrm{~min}$.; $21 \mathrm{~min}$. $5 \mathrm{~min}$. $=105 \mathrm{~min}$. for all plots in 2-hour intervals). A bee landing on an open flower for 5-10 seconds was considered to be a 'visit'. Observations of bee visitation were recorded on first (11 Oct, 2009), third (13 Oct), fifth day (15 Oct) and seventh (17 Oct) days after spraying the attractants. This process was repeated after a second spray of attractants during the 50 percent blooming period. Post-spray bee visitation was again enumerated on the $19 \mathrm{th}, 21^{\mathrm{st}}$, and $23^{\text {rd }}$ of October 2009. In addition to counting total visits, observers recorded (by sight) the relative number of honeybee flower visitors from each of the following species: Apis cerana, Apis florea, and Apis dorsata.

\section{Harvest parameters}

On $20^{\text {th }}$ November 2009, the tagged flower heads were harvested from each treatment and control plot and the number of seeds per head was recorded. Dried seed-weights were also recorded from each replicate and the data were statistically analyzed.

\section{Qualitative parameters}

Seeds from tagged flower heads were collected from all treatment and control plots. They were sun-dried and preserved for laboratory analysis.

\section{Moisture Content}

The moisture content for dried seeds was estimated by periodic weighing (4-hr intervals) of samples kept in an oven $\left(90^{\circ} \mathrm{C}\right)$ until a constant weight was recorded for three or more measurements. 


\section{Oil Content}

From these samples, 10 grams of seeds were collected randomly from both treatment and control groups for oil content analysis (performed at the Regional Research Station, Raichur using nuclear magnetic resonance methods per Wakhle et al., 1978).

\section{Germination}

100 seeds from each replicate (i.e., treatment and control) were placed on moistened coarse germination paper and kept in Petri plates. Plates were placed in a germination chamber at $20^{\circ} \mathrm{C}$ and $90 \%$ relative humidity. Germination counts were recorded. For evaluating seedling vigor, 10 rooted seedlings were selected from each replicate and shoot and root lengths were recorded 7 days after germination (Guruprasad and Viraktamath, 2003).

\section{Climatic conditions and Statistical analysis}

Meteorological data including average temperatures, relative humidity, wind speed, and sunlight during the experimental period was obtained from the University of Agricultural Sciences' Meteorological Center located $\sim 2 \mathrm{~km}$ from the experimental station. All response variables were analyzed statistically by one-way ANOVA and a DMRT (Duncans Multiple Range Test) using SPSS (version 11.0).

\section{RESULTS}

\section{Bee Visitation: First spray (10\% flowering)}

The relative abundance based on honeybee visitation (Apis cerana, A. dorsata and A. florea) to niger flowers on first day after the first spray (1DAFS) was greatest for the Fruit Boost plots treated with $0.75 \mathrm{ml} / \mathrm{l}$ and the Bee-Q plots treated with $12.5 \mathrm{~g} / \mathrm{l}$ (5.26 and $4.80 \mathrm{bees} / 10$ flowers $/ 5$ min) were most effective at $5 \% \mathrm{CD}$. The next most effective doses were Fruit boost at $0.5 \mathrm{ml} / 1$ and Bee-Q at $10 \mathrm{~g} / \mathrm{l}$. Each dosage equally attracted bees than the controls (4.00 compared to 2.60 bees $/ 10$ flowers $/ 5 \mathrm{~min}$ ). Raw data and statistics are provided in Table 1a. There was a stepwise increase in the number of honeybee flower visitors in the plots treated with Fruit boost at $0.75 \mathrm{ml} / 1$ ( 7.53 bees $/ 10$ flowers $/ 5 \mathrm{~min}$ ) and Bee-Q at $12.5 \mathrm{~g} / \mathrm{l}$ ( 6.40 bees $/ 10$ flowers $/ 5 \mathrm{~min}$ ). On the third day after the first spray (3DAFS), visitation on Fruit boost plots with 1.0 and $0.5 \mathrm{ml} / 1$ dosing also showed significant results over controls $(5 \% \mathrm{CD})$.
There was also a significant increase in number of honeybee flower visitors to plots treated with Fruit boost at a dosage of $0.75 \mathrm{ml} / \mathrm{l}$ and Bee-Q at 12.5 $\mathrm{g} / \mathrm{l}$ (8.26 and 7.13 bees/10 flowers $/ 5 \mathrm{~min})$. Fruit boost at $1.00 \mathrm{ml} / \mathrm{l}$ and Bee-Q at $10 \mathrm{~g} / \mathrm{l}$ showed equal effectiveness ( 5.46 bees / 10 flowers $/ 5 \mathrm{~min}$ ) compared to each other and a significant increase over controls ( 2.53 bees/10 flowers $/ 5 \mathrm{~min})$ on the fifth day after the first spray (5DAFS). On the seventh day after the first spray (7DAFS), plots treated with Fruit boost at $0.75 \mathrm{ml} / 1$ and Bee-Q at $12.5 \mathrm{~g} / \mathrm{l}$ were the most effective; however, each was less effective at 7DAFS than 3DAFS and 5DAFS, respectively. Fruit boost at $1.0 \mathrm{ml} / 1$ and Bee-Q at $10 \mathrm{~g} / \mathrm{l}$ and were more effective $(5 \% \mathrm{CD})$ than controls (2.53 bees $/ 10$ flowers $/ 5 \mathrm{~min})$ at 7DAFS.

Bee Visitation: Second spray (50\% flowering) The first day after the second spray (1DASS), more honeybees (5.33 and 4.66 bees/10 flowers / $5 \mathrm{~min}$ ) visited plots that received Fruit boost at 0.75 $\mathrm{ml} / \mathrm{l}$ and Bee-Q at $12.5 \mathrm{~g} / \mathrm{l}$, respectively (see Table 1b). These were followed by significant increases over control $(5 \% \mathrm{CD})$ on plots with Fruit boost at $0.5 \mathrm{ml} / 1$ and Bee-Q at $10.0 \mathrm{~g} / \mathrm{l}(4.0$ bees/10 flowers/5 min). Raw data and statistics are provided in Table- $1 \mathrm{~b}$. On the third day after the second spray (3DASS), there was a significant increase over the control (5\% CD) in number of honeybee visitors to plots treated with Fruit boost at $0.75 \mathrm{ml} / \mathrm{l}$ and Bee-Q at $12.5 \mathrm{~g} / \mathrm{l}$. Fruit boost at $0.5 \mathrm{ml} / 1$ and Bee-Q at $15 \mathrm{~g} / \mathrm{l}$ were equally effective (both showed 4.33 bees $/ 10$ flowers $/ 5 \mathrm{~min}$ ) and showed a significant increase compared to controls for 3DASS. On 5th day after second spray (5DASS), Bee-Q at $12.5 \mathrm{~g} / \mathrm{l}$ had the greatest effect (5.33 bees $/ 10$ flowers $/ 5 \mathrm{~min}$ ) followed by Fruit boost at $0.75 \mathrm{ml} / 1$ (5.00 bees $/ 10$ flowers $/ 5 \mathrm{~min})$. Fruit boost at $1 \mathrm{ml} / \mathrm{l}$ also showed a significant effect (5\% CD) compared to controls.

\section{Harvest parameters}

Yield data are provided in Table 2. The number of seeds per head was greatest in plots treated with Fruit boost at $0.75 \mathrm{ml} / 1$ (30.66 seeds/head representing a $29.58 \%$ increase over control). Similar results were observed for plots treated with Bee-Q at $12.5 \mathrm{~g} / \mathrm{l}$ (30.33 seeds/head, which represents a $28.19 \%$ increase over control. Plots treated with Fruit boost at $1.0 \mathrm{ml} / \mathrm{l}$ also showed significant increases over control $(23.96 \%, 5 \%$ CD). For Thousand-Count Seed Weight (TCSW), 
plots that received Fruit boost at $0.75 \mathrm{ml} / \mathrm{l}$ showed the greatest seed mass at 3.63 grams per 1000seeds, representing a $19.80 \%$ increase over the control. Plots treated with Bee-Q at $12.5 \mathrm{~g} / \mathrm{l}$ also showed a significant difference in TCSW ( $3.55 \mathrm{~g} / 1000$ seeds), which equated to a $17.16 \%$ increase over control. Fruit boost at $0.5 \mathrm{ml} / \mathrm{l}$ and Bee-Q at $15 \mathrm{~g} / \mathrm{l}$ resulted in equivalent TCSW values $(3.10 \mathrm{~g} / 1000$ seeds $)$, which were significantly greater than control conditions $(2.31 \%$ increase at $5 \% \mathrm{CD})$.

Table 1 - (a) and (b): Bee-attractants and honeybee-visitation, showing all 7 treatments with first (10\%) and second $(50 \%)$ spray on Niger.

\begin{tabular}{|c|c|c|c|c|c|c|c|}
\hline \multirow{3}{*}{ Treatments } & \multicolumn{7}{|c|}{ Number of honeybees / 10 flowers / 5 min } \\
\hline & \multicolumn{4}{|c|}{ (a) First Spray (10\% flowering) } & \multicolumn{3}{|c|}{ (b) Second spray (50\% flowering) } \\
\hline & 1 DAFS & 3DAFS & 5 DAFS & 7 DAFS & 1 DASS & 3 DASS & 5 DASS \\
\hline T1-Bee-Q @ 10 gms/ltr & $4.00 \mathrm{a}$ & $3.13 \mathrm{c}$ & $5.46 \mathrm{~b}$ & $4.93 \mathrm{~b}$ & $4.00 \mathrm{~b}$ & $3.66 \mathrm{c}$ & $3.33 \mathrm{c}$ \\
\hline T2-Bee-Q @ 12.5 gms/ltr & $4.80 \mathrm{a}$ & $6.40 \mathrm{a}$ & $7.13 \mathrm{a}$ & $6.00 \mathrm{a}$ & $4.66 \mathrm{a}$ & $5.66 \mathrm{a}$ & $5.33 \mathrm{a}$ \\
\hline T3-Bee-Q @ 15 gms/ltr & $3.80 \mathrm{~b}$ & $4.86 \mathrm{~b}$ & $5.06 \mathrm{~b}$ & $4.40 \mathrm{c}$ & $3.33 \mathrm{~b}$ & $4.33 \mathrm{~b}$ & $4.00 \mathrm{~b}$ \\
\hline T4-Fruit boost @ 0.5ml/ltr & $4.00 \mathrm{a}$ & $5.26 \mathrm{~b}$ & $5.06 \mathrm{~b}$ & $4.40 \mathrm{c}$ & $4.00 \mathrm{~b}$ & $4.33 \mathrm{~b}$ & $4.00 \mathrm{~b}$ \\
\hline T5-Fruit boost @ 0.75ml/1tr & $5.26 \mathrm{a}$ & $7.53 \mathrm{a}$ & $8.26 \mathrm{a}$ & $6.66 \mathrm{a}$ & $5.33 \mathrm{a}$ & $5.33 \mathrm{a}$ & $5.00 \mathrm{a}$ \\
\hline T6-Fruit boost @ 1ml/ltr & $3.73 \mathrm{~b}$ & $5.53 \mathrm{~b}$ & $5.46 \mathrm{~b}$ & $4.86 \mathrm{~b}$ & $3.66 \mathrm{~b}$ & $3.66 \mathrm{c}$ & $4.33 \mathrm{~b}$ \\
\hline T7- control(Unsprayed plot) & $2.60 \mathrm{~b}$ & $2.40 \mathrm{~d}$ & $2.53 \mathrm{c}$ & $2.53 \mathrm{e}$ & $2.33 \mathrm{c}$ & $3.33 \mathrm{c}$ & $3.00 \mathrm{c}$ \\
\hline F-Value & $*$ & $*$ & $*$ & $*$ & $*$ & $*$ & $*$ \\
\hline SE & 0.455 & 0.479 & 0.492 & 0.230 & 0.238 & 0.20 & 0.245 \\
\hline $\mathrm{CD}$ at $5 \%$ & 1.315 & 1.385 & 1.422 & 0.665 & 0.702 & 0.590 & 0.722 \\
\hline
\end{tabular}

DBFS-Day before first spray DBSS-Day before second spray ${ }^{*}$-Significant at $5 \%$ level.

DASS-Day after second spray $\quad$ SE- Standard error DAFS - Day after first Spray

Table 2 - Effect of Bee attractants on the Quantitative Parameters in Niger.

\begin{tabular}{ccccc}
\hline \multirow{2}{*}{ Treatments } & \multicolumn{2}{c}{ Number of seeds / head } & 1000 seed weight (gm) \\
\cline { 2 - 5 } & Mean & $\begin{array}{c}\text { \% Increase / Decrease } \\
\text { Over OP }\end{array}$ & Mean & $\begin{array}{c}\text { \% Increase / } \\
\text { Decrease over OP }\end{array}$ \\
\hline T1-Bee-Q @ 10 gms/ltr & $25.00 \mathrm{~b}$ & 5.66 & $3.05 \mathrm{~b}$ & 0.66 \\
T2-Bee-Q @ 12.5 gms/ ltr & $30.33 \mathrm{a}$ & 28.19 & $3.55 \mathrm{a}$ & 17.16 \\
T3-Bee-Q @ 15 gms/ ltr & $26.33 \mathrm{~b}$ & 11.28 & $3.10 \mathrm{~b}$ & 2.31 \\
T4-Fruit boost @ 0.5ml/ltr & $29.00 \mathrm{a}$ & 22.56 & $3.10 \mathrm{~b}$ & 2.31 \\
T5-Fruit boost @ 0.75ml/ltr & $30.66 \mathrm{a}$ & 29.58 & $3.63 \mathrm{a}$ & 19.80 \\
T6-Fruit boost @ 1ml/ltr & $29.33 \mathrm{a}$ & 23.96 & $3.06 \mathrm{~b}$ & 0.99 \\
T7-Control (Unsprayed plot) & $23.66 \mathrm{c}$ & - & $3.03 \mathrm{~b}$ & - \\
F-value & $*$ & & 0.107 & 0.315 \\
SE & 0.759 & & & \\
CD at 5\% & 2.241 & *-Significant at 5\% level; & Means followed by the same letter in a column do not differ significantly by DMRT.
\end{tabular}

In Table 3, growth, maturation, and chemical composition data for niger are provided. We found a numeric increase in oil content from flowers on plots treated with Fruit boost at $0.75 \mathrm{ml} / \mathrm{l}$ and Bee$\mathrm{Q}$ at $12.5 \mathrm{~g} / \mathrm{l}$ (40.43\% and $40.73 \%$, respectively), compared to controls (36.30\%); however, this was not significant at $5 \% \mathrm{CD}$. Increase in plant germination with Fruit boost treatments at 0.75 $\mathrm{ml} / \mathrm{l}$ (90.33\%) was significant; specifically, a $20.98 \%$ increase over control was noted. Plots treated with Bee-Q at $12.5 \mathrm{~g} / \mathrm{l}$ also increased germination (89.33\%), representing a $19.64 \%$ increase over control. This treatment was on par with Fruit boost at $1 \mathrm{ml} / \mathrm{l} \quad(88.66$ percent, representing a $18.75 \%$ increase over control). Plots treated with Fruit boost at $0.75 \mathrm{ml} / \mathrm{l}$ seemed to increased average root lengths $(8.81 \mathrm{~cm}$ compared to $8.25 \mathrm{~cm}$ for the control). However, this was not statistically significant. Although Bee$\mathrm{Q}$ treatment at $12.5 \mathrm{~g} / \mathrm{l}$ similarly showed a $4.96 \%$ increase over controls, this was also not statistically significant. Likewise, Fruit boost at $0.75 \mathrm{ml} / \mathrm{l}$ and Bee-Q at $12.5 \mathrm{~g} / \mathrm{l}$ appeared to enhance average shoot length in plants; however, these data not statistically significant.

\section{Climatic conditions}

The data on the climatic factors of Niger is given in Table 4. These data showed no significant 
correlation between bee visitation, yield, and

qualitative parameters (as defined in Table 3).

Table 3 - Effect of bee attractants on the Qualitative parameters in Niger.

\begin{tabular}{|c|c|c|c|c|c|c|c|c|}
\hline \multirow[b]{2}{*}{ Treatments } & \multicolumn{2}{|c|}{$\begin{array}{l}\text { Percentage of Oil } \\
\text { content }(\%)\end{array}$} & \multicolumn{2}{|c|}{$\begin{array}{c}\text { Germination } \\
\text { percentage }(\%)\end{array}$} & \multicolumn{2}{|c|}{ Root Length (cm) } & \multicolumn{2}{|c|}{ Shoot length $(\mathrm{cm})$} \\
\hline & Mean & $\begin{array}{c}\% \text { Increase / } \\
\text { Decrease over } \\
\text { OP }\end{array}$ & Mean & $\begin{array}{c}\text { \% Increase / } \\
\text { Decrease over } \\
\text { OP }\end{array}$ & Mean & $\begin{array}{c}\text { \% Increase / } \\
\text { Decrease over } \\
\text { OP }\end{array}$ & Mean & $\begin{array}{c}\% \text { Increase / } \\
\text { Decrease over } \\
\text { OP }\end{array}$ \\
\hline T1-Bee-Q @ 10 gms/ltr & $39.40 \mathrm{a}$ & 8.53 & $82.66 \mathrm{c}$ & 10.71 & $8.33 \mathrm{a}$ & 0.96 & $8.28 \mathrm{a}$ & 24.32 \\
\hline T2-Bee-Q @ 12.5 gms/ltr & $40.73 \mathrm{a}$ & 12.20 & $89.33 \mathrm{a}$ & 19.64 & $8.66 \mathrm{a}$ & 4.96 & $8.63 \mathrm{a}$ & 29.57 \\
\hline T3-Bee-Q @ 15 gms/ltr & $38.73 \mathrm{a}$ & 6.69 & $83.00 \mathrm{c}$ & 11.17 & $8.50 \mathrm{a}$ & 3.03 & $8.31 \mathrm{a}$ & 24.77 \\
\hline T4-Fruit boost @ 0.5ml/1tr & $39.40 \mathrm{a}$ & 8.53 & $83.33 \mathrm{~b}$ & 11.61 & $8.36 \mathrm{a}$ & 1.33 & $8.31 \mathrm{a}$ & 24.77 \\
\hline T5-Fruit boost @ 0.75ml/1tr & $40.43 \mathrm{a}$ & 11.37 & $90.33 \mathrm{a}$ & 20.98 & $8.81 \mathrm{a}$ & 6.78 & $8.41 \mathrm{a}$ & 26.27 \\
\hline T6-Fruit boost @ 1ml/ltr & $39.60 \mathrm{a}$ & 9.09 & $88.66 \mathrm{a}$ & 18.75 & $8.41 \mathrm{a}$ & 4.60 & $8.20 \mathrm{a}$ & 23.12 \\
\hline T17- Control (Unsprayed plot) & $36.30 \mathrm{a}$ & - & $74.66 \mathrm{~d}$ & - & $8.25 \mathrm{a}$ & - & $6.66 \mathrm{~b}$ & - \\
\hline F-value & -- & & $*$ & & -- & & -- & \\
\hline SE & 1.275 & & 0.856 & & 0.372 & & 0.378 & \\
\hline $\mathrm{CD}$ at $5 \%$ & NS & & 2.526 & & NS & & NS & \\
\hline
\end{tabular}

Table 4 - Environmental conditions (average) during seven treatments conducted on Niger.

\begin{tabular}{ccccc}
\hline Date & Temperature $(\circ \mathbf{C})$ & Relative Humidity $\mathbf{\%})$ & Cumulative wind (km) & Sun light (hrs) \\
\hline Oct -11 -2009 & 25.9 & 64.0 & 50 & 8.4 \\
Oct -13 -2009 & 29.6 & 66.5 & 70 & 9.2 \\
Oct -15 -2009 & 31.8 & 57.0 & 40 & 8.9 \\
Oct -17 -2009 & 30.3 & 67.0 & 50 & 7.8 \\
Oct -19 -2009 & 24.2 & 72.5 & 50 & 4.0 \\
Oct -21 -2009 & 24.8 & 70.5 & 40 & 3.8 \\
Oct -23 -2009 & 23.0 & 92.0 & 50 & 3.5 \\
\hline
\end{tabular}

\section{DISCUSSION}

These data show a general benefit in the use of honeybee attractants to promote pollination on niger. There is evidence that Fruit boost at 0.75 $\mathrm{ml} / \mathrm{l}$ and Bee-Q at $12.5 \mathrm{~g} / \mathrm{l}$ maximally increases the total number of honeybee flower visitations at 5DAFS. For the second spray, the data are more variable. However, it appears that the third day after a second spray with Fruit boost at $0.75 \mathrm{ml} / 1$ or Bee-Q at $12.5 \mathrm{~g} / \mathrm{l}$ is also effective in attracting more bees. This is in line with another report that showed that Fruit boost at $0.5 \mathrm{ml} / 1$ had a significant effect in attracting more pollinators. (Guruprasad and Viraktamath 2003).

Notably, effectiveness waned at 7DAFS perhaps due to wearing of attractant and a decrease in detection. There was a modest but statistically significant increase in number of seeds/head in plots treated with Fruit boost at $0.75 \mathrm{ml} / \mathrm{l}$ and Bee$\mathrm{Q}$ at $12.5 \mathrm{~g} / \mathrm{l}$ sprayed plots. There was a marginal increase in TCSW on plots treated with Fruit boost at $0.75 \mathrm{ml} / 1$ and Bee-Q at $12.5 \mathrm{~g} / 1$ sprayed plots. Consequently, more seed set and a greater TCSW is expected in cases where crops are open to all pollinators (Choudhary et al. 2003).

There was no significant increase in oil content of niger. However, germination percentage is significantly enhanced with Fruit boost application at $0.75 \mathrm{ml} / \mathrm{l}$ and Bee-Q application at $12.5 \mathrm{~g} / \mathrm{l}$. Increase in germination percentage in niger (attributed to frequent bee visitation) has been previously reported (Kulkarni and Dhanorkar 1998). Neither Fruit boost nor Bee-Q was shown to significantly impact root length and shoot length. Cumulatively, these data suggest that Fruit boost can enhance germination and seed vigor as previously reported (Guruprasad and Viraktamath 2003).

In conclusion, it appears that Fruit boost at 0.75 $\mathrm{ml} / \mathrm{l}$ and Bee-Q at $12.5 \mathrm{~g} / \mathrm{l}$ sufficiently increase honeybee visitation on flowers of niger and generally improve pollination performance when comparison to untreated control plots. Increased bee visitation to this plant results in marginal increases in yield, including the number of seeds/head and TCSW. This is due to increases in both the forager number and inter-floral pollen 
movement. In case of Bee-Q, which is a food attractant rich in carbohydrates, a phagostimulatory effect may also contribute to increased yields in niger. Overall, this study suggests that the use of bee attractants may serve as an effective management tool for improving the efficiency and consistency of pollination and productivity.

\section{ACKNOWLEDGEMENTS}

We greatly acknowledge the Department of Botany, Bangalore University, Bangalore, India for facilities; Prof. Surendra, Department of Statistics, University of Agricultural Sciences, G.K.V.K campus, Bangalore, India for his valuable suggestions on statistical analysis; Lakshmana Gowda, beekeeper who helped with bee hives for this research work, and my colleagues Ms. Chandrama Singh and Ms. Chethana V C for their help wherever possible.

\section{REFERENCES}

Ambrose JTJr., Schultheis SB, Bambara Mangum W. An evaluation of commercial bee attractants in the pollination of cucumbers and watermelons, American Bee J. 1995; 135: 267-272.

Bhambure CS. Effect of honeybee activity on Niger seeds production, Indian Bee J. 1958; 20:189-195.

Chandrashekar GS, Sattigi HN. Influence of bee attractants on bee pollination on seed quality and yields in radish, Karnataka J. Agric.Sci. 2009; 22(4): 777-788.

Choddury NK, Chand H, Singh R, Singh AK. Foraging behaviour and pollination efficiency of honeybees in Niger (Guizotia abyssinica Cass), Asian Bee J. 2003; 5(1-2): 119-123.

Currie RW, Winston ML, Slessor KN, Mayer DF. Effect of synthetic queen mandibular pheromone sprays on pollination of fruit crop by honey bees (Hymenoptera: Apidae), J. Economic Entomol. 1992a; 85(4): 12931299.

Currie RW, Winston ML, Slessor KN. Effect of synthetic queen mandibular pheromone sprays on honeybee (Hymenoptera: Apidae) pollination of Berry crops, $J$. Economic Entomol. 1992b; 85(4): 1300-1306.

Delaplane KS, Mayer DF. Crop pollination by bees. Wallingford, United Kingdom: CABI; 2000.

Elmstorm GW, Maynard DN. Attraction of honeybees to the watermelon with bee attractant, Proc.Florida state Horti Soc. 1991; 103:130-133.

Guruprasad GS, Viraktamath S. Efficacy of bee attractants in maximization of seed yield of Niger, J. Palynol. 2003; 39: 31-37.
Levin DA, Anderson WW. Competition for pollinators between simultaneously flowering species. The American Naturalist. 1970; 104(939): 455-467.

Higo H.A., Winston M.L., Slessor K.N. Mechanism by which honeybee (Hymenoptera: Apidae) queen pheromone sprays enhance pollination, Annals Entomol Soc. America. 1995; 88: 366-373.

Kalmath S, Sattigi SN. Use of Attractants in maximising the quantitative parameters of onion (Allium cepa L.) seed, Indian Bee J. 2002; 64(3-4): 11-15.

Kulakarni SN, Dhanorkar BR. Effect of Apis cerana indica on Niger seed production in Marathwada region. FAO workshop on sustainable beekeeping development and all India honey festival: $1-5^{\text {th }}$ August; Dharwad, India. 1998.

Mayer DF, Britt RL, Lundon JD. Evaluation of Bee Scent as a honeybee attractant, American Bee J. 1989a; 129: 41-42.

Mayer D.F., Britt R.L., Lundon J.D. Evaluation of Bee Scent as a honeybee attractant. Good Fruit Grower. 1989b; 40: 40.

Naumann K, Winston ML, Slessor KN, Smirle MJ. Synthetic honeybee (Hymenoptera: Apidae) queen mandibular gland pheromone applications affect pear and sweet cherry pollination, J. Economic Entomol. 1994; 87: 1595-1599.

Panchabhavi KS, Jai Rao K. Note on the effect of mixed cropping of Niger on the activities of insect pollinators and seed filling of sunflowers in Karnataka, Indian $J$. Agric. Sci. 1978; 48(4): 254-255.

Panda P, Sontakke BK, Sarangi PK. Preliminary studies on the effect of honeybees (Apis cerana indica F.) Pollination on yield of sesamum and Niger, Indian Bee J. 1988; 50(3): 63-64.

Pateel MC, Sattigi HN. Effect of different attractants on attracting the Bees to Cucumber (Cucumis sativus L.) crop, Karnataka J. Agric.Sci. 2007; 20(4): 761-763.

Ramachandran TK, Madhava menon P. Pollination mechanism and inbreeding depression in Niger (Guizotia abyssinica Cass.), Madras Agric J. 1979; 66(7): 449-454.

Rao GM, Suryanarayana MC. Studies on the foraging behaviour of honeybees and its effect on the seed yield in Niger, Indian Bee J. 1990; 52: 32-33.

Sivaram V, Jayaramappa KV. Role of commercial bee attractants in pollination and yield parameters of Niger, XXIII International Congress of Entomology: July 6$12^{\text {th }}$, South Africa. 2008

Viraktamath S, Anagoudar. Influence of bee attractants in enhancing pollination and yield parameters in Cucumis sativus L. Indian Bee J. 2002; 64(1-2): 23-27.

Wakhle DM, Shakuntala Nair K, Phadhke RP. Effect of Bee pollination on the oil and protein content in the seeds of Sunflower (Helianthus annus L.), Indian Bee J. 1978; 40:1-2.

Winston ML, Slessor KN. Application of queen honeybee mandibular pheromone for beekeeping and crop pollination, Bee world. 1993; 74:11-128. 